\title{
Implementing Circumlocution to Improve the Speech Performance in Public Speaking
}

\author{
$1^{\text {st }}$ D R Santoso \\ English Education Study Program, \\ Universitas Muhammadiyah Sidoarjo \\ Kampus I J1. Mojopahit 666B Sidoarjo \\ Indonesia \\ dianrahma24@umsida.ac.id
}

\author{
$2^{\text {nd }} W$ Taufiq \\ English Education Study Program, \\ Universitas Muhammadiyah Sidoarjo \\ Kampus I Jl. Mojopahit 666B Sidoarjo \\ Indonesia
}

\begin{abstract}
This study aims to investigate how students can improve their speech performance by using circumlocution, one of communication strategies. The design used is classroom action research (CAR) implemented into two cycles. At the first cycle, the theme given is informative speech. While the second one, the theme is persuasive speech. The subjects of the study are fifty-three students of two public speaking classes. Both classes have difficulties in performing speeches confidently especially when they lost their mind in the middle of the speech. The students prefer writing and memorizing script to using draft which makes the performance worse. In the treatment, the students were divided into groups and evaluate each other's performance. The result showed that all students could improve their communication skill through circumlocution strategy. Another result shows that the students can also increase their confidence in presenting the speech. Besides, despite delivering the good content of the speech and performed with appropriate gestures, the students could develop their performance without looking at the whole script.
\end{abstract}

\section{Keywords-Circumlocution, Speech, Public Speaking}

\section{INTRODUCTION}

Studies on public speaking nowadays are very popular. Speaking in front of public is often related to the way of communication because it is usually used at the same time to share information to the audience or listeners. How people communicate actually shows their credibility in public. Although not everyone is destined to be a public speaker, it is a really matter to learn to be one as well.

In line with public speaking and communication, most students of English Education study program of Universitas Muhammadiyah Sidoarjo still have problems to communicate confidently in front of public. When people became the focus of attention in front of such audience, they would feel afraid and anxiety, even lead to nausea and produced much sweat. They mostly avoid performing or speaking in front of public, yet if it could not be avoided, that condition could be stressful [1]. Public speaking helps the students to brush up their personal and social interaction, academic improvement and career benefit. By practicing public speaking, students could develop confidence to persuade other people with ideas and opinion [2].

Preliminary studies mentioned that most students were afraid of making grammatical mistakes, lack of vocabulary, get confused to develop the outline when performing. The students have to speak without making long script, memorizing it and performing; but they must write outline and use it as the guideline to speak in front of many people. Within this condition, the students who do not get used to speaking in front of public by using outline will appear unconfident to present the speech performance.

Related to public speaking, a speaker should explore the topic, express the idea, analyse critically and make the audience understand the whole context of speech [3]. Furthermore, making outline is much easier than writing script before performing speeches, but in the middle of the speech, some students are suddenly silent, or say "umm" of repeat the previous explanation. They even looked nervous and the voice could not appeal because they forget what to say even if they hold the outline.

In terms of confidence, Mufanti, et. al. investigates the students who joined the program of public speaking intensive course. The program was expected to helps them raise their competency and reduce their anxiety to enhance the students' competence in public speaking. For two years they did the successful program, it was clearly stated that most problem the students faced in public speaking was caused by lack of confidence [4].

Besides, Arniatika investigated the specific problems in speaking. Students took too much time to think before speaking and they even do not have any idea what to say [5]. These kinds of problems made the researchers who are also English lecturers understand learning a foreign language is challenging and it takes much time.

Despite the teachers or lecturers' need to motivate, stimulate and encourage the students; they need to be aware of the communication strategies to help them to improve their speech performance in public speaking class. 
Therefore, this study is expected to answer the problem of how circumlocution, a strategy of communication strategies, can improve the speech performance of public speaking.

Brown described five taxonomies in speaking. First, imitative expect the students to imitate the word, phrase and sentence they hear. Second, Intensive needs productivity from short structure that shows the relationship of grammar, phrase, lexical and phonology. Third, responsive means the duties which involves interaction and comprehension test in a limited level and a simple way. Fourth, interactive tasks concern with the complex and long interaction of speaker and listener to exchange the information and keep good relation. fifth, extensive (monolog) concerns with the task that needs perfomance like presentation or speech, debating and story-telling.

Rybold explained the linear model of organizing speeches which include introduction, thesis statement, preview, body, summary, conclusion. Horwitz et al. (in Sutarsyah) explained that in communication apprehension, most language learners have difficulty not only in speaking but also listening to comprehend messages from others.

Speaking performance is the act of conveying messages from the speaker to the listener through words, utterance, and sentences where their performance in speaking will automatically show their good or bad competence either [5]. Tuan and Mai quoted by Dayat stated some factors make students' performance are such topical knowledge, listening ability, motivation to speak, teachers' feedback during speaking activities, confidence, the pressure to perform well, and time for preparation [6]. To support the evaluation of the speech performance, the researchers use the guideline from Santoso which contains eight point of evaluation. (see appendix)

Yaman, Irgin \& Kavasoglu conveyed from the theories written by Dörnyei \& Scott, and Tarone, divided communication strategies into three categories: direct, indirect and interactional strategy. First, the direct strategy means alternative, manageable and self-contained thing to get the across meaning. It contains message reduction, circumlocution, approximation, code switching, mime, self-rephrasing, self-repair and other repair. Second, indirect strategy involves fillers and repetition to facilitate the meaning by making such situation to extend the time. Third, interactional strategy, which include cooperative problem-solving with the appeal for help, comprehension check, asking for repetition and guessing [7].

Dörnyei \& Scott defined those strategies; first, the message abandonment is the strategy to leave unfinished message, meaning the speaker stops speaking when forgot certain vocabulary or sentences. Second, topic avoidance means that the speaker avoids to talk about the concepts they think difficult to utter. Third, circumlocution means describing objects. Forth, approximation, refers to applying the same term which express the same meaning of the target vocabulary. Fifth, word coinage, means creating a nonexisting target language. Sixth, the literal translation means the speaker translates the terms, such as the idioms, compound words, and its structure literally, from original language to the target language. Seventh, foreignizing means creating non-existent target language vocabulary by applying morphology or phonology to the original language vocabulary. Eighth, code switching, means inserting a word, phrase or statement. Ninth, appeal for help, refers to the speaker who asks for help about the words they forgot or they have no knowledge about it in the target language.

Dornyei, as cited in Majd, explained circumlocution as describing or exemplifying the target object or action [8]. The students tend to use paraphrasing and also positive and reinforcing comments to make students confident in their use of English. What they did was encouraging other students to restructure their questions and replying with complete sentences [9]. Tarone, in Maleki defined circumlocution as the learners described the characteristics or elements of an object or action instead of using the appropriate target language structure (for example: She is, umm, smoking something. I don't know what's its name. That's, umm, Persian, and we use in Turkey a lot of) [10]. Hua, Nor \& Jaradat mentioned that Circumlocution means the learners describe or exemplify the action of object instead of using the right L2 structure or item [11].

In this study, the researcher told the students to explore circumlocution by describing something and add more sentences in the middle of the speech. For example: in case a speaker, say Andy, wants to correlate between the use of veil and student's character. Then, he forgot to say veil in the middle of the speech because of stage frightened. He can change the word veil with something or cloth that covers girl's upper body from hair to chest.

\section{METHODS}

The research design used was Classroom Action Research (CAR) which include four steps of planning, acting, observing and reflecting [12]. The data source was taken from fifty-three students of fourth semester of English Education Study Program Academic year 2019/2020 who took Public Speaking Lecture.

In planning stage, the students worked individually. The video camera is needed to record the speech performance, in this case, each student used their personal gadget to record their own performance. The material was informative speech, and the topic was education in Indonesia. The students could specify the topic into titles they like. The criteria of success were determined that all students could meet minimum score 70 of the range from 0 to 100 by using public speaking evaluation guide.

Next, in acting stage, all students work individually performing speeches. In the middle of the speech, when they are upset, they have to implement circumlocution strategy to describe things or object to replace the missing vocabulary or sentences.

Furthermore, in observing stage, the data were collected from their performance. The field note was used to report the verbal data of the students' participation and attitude. The test was to retrieve numerical data from the score of the preliminary study and the post test.

Last, reflecting stage covered the data analysis the cycle one. It indicated the result of observation by giving feedback and evaluation of each performance. The data were analyzed by synthesizing, summarizing and 
interpreting. The verbal data related to the students' activities was gained from the field note. The numerical data was taken from the individual test.

\section{RESULTS AND DISCUSSION}

\section{A. Research Finding}

The study was accomplished in two cycles of eight meetings. The first four-meeting required students to perform informative speech with education topic. Whereas the second cycle required persuasive speech with selling products or services topic. The students' improvement of speech performance of public speaking is presented in the following table.

\begin{tabular}{|c|c|c|c|}
\hline & Towest Score & Highest Score & Average Score \\
\hline Preliminary & 52 & 60 & 56 \\
\hline Cycle 1 & 64 & 72 & 68 \\
\hline Cycle 2 & 72 & 40 & 74 \\
\hline
\end{tabular}

The finding above shows that there is an improvement after two cycles of the classroom action research. All could meet the minimum score means the implementation of circumlocution, as one of the communication strategies, is successful to increase their speech performance.

\section{B. Discussion}

The improvement from preliminary study to the process of cycle one shows good progress but not meet the minimum requirement score 70 . In cycle one, fewer than $50 \%$ students seemed becoming credible sources of information related to informative speech. They could be good informants who inform any materials related with the education in Indonesia. However, this topic represents one way speaking without considering the audience's attention to believe what the speaker said.

In the part of implementing circumlocution, few students tried to rephrase the terms to catch audience's selfinterest when they lost their mind and forgot what to say in the middle of the speech. In fact, they tried to use facts and logical reasoning to support their views. That statement is in line with the definition of circumlocution, according to Tarone, in Maleki, as the learners described the characteristics or elements of an object or action instead of using the appropriate target language structure [10].

In addition, forty percent of the students could organize their speech properly. They used speech outline instead of memorizing long script. Even though, in a certain case, they lacked of using emotion to persuade the audience to support their views even though some speeches showed the opening could capture the audience's interest.

In contrary, those who had not met the minimum score, their body language and vocal variety not optimally contribute to the message. Most students still look at the script they put on the left or right of their gadget. The video of speech performance indicates that students could have not released their script away and replace with outlines. This condition makes not many audiences persuaded to accept the speaker's views.

The second cycle showed different result. More than $75 \%$ students became credible sources of information in presenting persuasive speech with selling products or services topic. They could persuade the audience to believe that their products or services were good. This topic truly considers the audience's attention to believe what the speaker said. This supports Brown's theory related to speaking category. Intensive needs productivity from short structure that shows the relationship of grammar, phrase, lexical and phonology.

In the part of implementing circumlocution, most students describe the object by mentioning the different terms of vocabulary, arranged into a better sentence to catch audience's self-interest when they lost their mind and forgot what to say in the middle of the speech. Indeed, they used facts and logical reasoning to support their views to make the audience believe what they said.

In other words, by using circumlocution, that statement strongly supports Cervantes and Rodriguez that showed the students used paraphrasing to check the students' understanding of the meaning of words, and that he gave explanations of the meanings of words [9].

Furthermore, most students could organize their speech properly. They used speech outline instead of memorizing long script. They truly forced themselves to uses other phrases to explain things they lost in mind in the middle of delivering the speech. Besides, they could show little emotion to persuade the audience to support their views although the speech opening could not optimally capture the audience's interest. In short, those all results showed that students could to attract the audience's attention with good delivery.

Finally, this study supports Popescu \& Vida which considered the Communicative Strategies could be a great help for many students to continue a conversation when they do not know the words or the structures, to gain confidence in speaking, to increase fluency, to appear interested in communicating, to develop a sense of autonomy. The teacher's role, they continued, is to help students to deal with past frustration and anxiety to build confidence [13]

\section{CONCLUSION}

Communication strategies used in the classroom provides students with alternative ways of expressing in English. Implementing circumlocution as one of the communication strategies truly helps the students to improve their speech performance in public speaking. The researchers believe, if the students continued speaking the same way as what they have done in cycle one and two, they could be even getting maximum score. More important than that, they could be public speakers. 
APPENDICES

TABLE II. EVALUATION GUIDE

\begin{tabular}{|c|c|c|c|c|c|c|}
\hline \multirow[t]{2}{*}{ No } & \multirow[t]{2}{*}{ Description } & \multicolumn{4}{|c|}{ Score } & \multirow[t]{2}{*}{ Comments } \\
\hline & & 4 & 3 & 2 & 1 & \\
\hline 1. & Was the speaker a credible source of information about this topic? & & & & & \\
\hline 2. & Did the speaker phrase his/her appeal in terms of the audience's self-interest? & & & & & \\
\hline 3. & Did the speech opening capture the audience's interest? & & & & & \\
\hline 4. & Did the speaker use facts and logical reasoning to support his or her views? & & & & & \\
\hline 5. & $\begin{array}{l}\text { Did the speaker properly use emotion to persuade the audience to support his or } \\
\text { her views? }\end{array}$ & & & & & \\
\hline 6. & Was the speech organization effective? & & & & & \\
\hline 7. & Did the speaker's body language and vocal variety contribute to the message? & & & & & \\
\hline 8. & Were you persuaded to accept the speaker's views? & & & & & \\
\hline
\end{tabular}

\section{ACKNOWLEDGMENTS}

Here I am Dian Rahma Santoso wishing to acknowledge assistance or encouragement from colleagues and great collaborative students of Universitas Muhammadiyah Sidoarjo, I am thankful for all unnumbered supports until this paper is published.

\section{REFERENCES}

[1] F. U. Raja, "Anxiety Level in Students of Public Speaking: Causes and Remedies," J. Educ. Educ. Dev., vol. 4, no. 1, p. 94 , 2017, doi: 10.22555/joeed.v4i1.1001.

[2] K. M. Yee, M. Jafre, and Z. Abidin, "The Use of Public Speaking in Motivating ESL Learners to Overcome Speech Anxiety," Int. J. Stud. English Lang. Lit., vol. 2, no. 11, pp. 128-129., 2014.

[3] D. R. Santoso, "Implementing Video Recording to Improve the Content of Opening Speech," JEES (Journal English Educ. Soc., vol. 2, no. 1, p. 21, 2017, doi: 10.21070/jees.v2i1.713.

[4] R. Mufanti, A. Susilo, R. A. Gestanti, and E. P. Nimasari, "PUBLIC SPEAKING INTENSIVE COURSE FOR STUDENTS OF NON- ENGLISH DEPARTMENT (A Study in English Language Centre)," Exposure, vol. 7, no. 2, pp. 161-178, 2018.

[5] S. Arniatika, "Improving Speaking Performance Through Pecha Kucha Presentation Method," Pedagog. J. English Lang. Teach., vol. 6, no. 2, p. 129, 2019, doi: 10.32332/pedagogy.v6i2.1329.

[6] D. Dayat, "Analysis on English Speaking Performance: Exploring Students' Errors and The Causes," JETL (Journal Educ. Teach. Learn., vol. 2, no. 1, p. 130, 2017, doi: 10.26737/jetl.v2i1.149.

[7] Ş. Yaman, P. Irgın, and M. Kavasoğlu, "İletişim Stratejileri:İngilizceyi Yabancı Dil Olarak Öğrenen Üniversite Öğrencilerine Yönelik Çıkarımlar,” J. Educ. Sci. Res., vol. 3, no. 2, pp. 255-268, 2013, doi: 10.12973/jesr.2013.3213a.

[8] Golaleh Majd, "<Majd.pdf $>$," English Specif. Purp. World, vol. 15, no. 42, 2014, [Online]. Available: www.esp-world.info.

[9] R. R. Rodriguez, "The Use of Communication Strategies in the Beginner EFL," vol. 6, no. 6, pp. 111-128, 2012.

[10] A. Maleki, "Techniques to Teach Communication Strategies," $J$. Lang. Teach. Res., vol. 1, no. 5, pp. 640-646, 2010, doi: 10.4304/jltr.1.5.640-646.

[11] T. K. Hua, N. F. M. Nor, and M. N. Jaradat, "Communication strategies among EFL students - An examination of frequency of use and types of strategies used," GEMA Online J. Lang. Stud., vol. 12, no. 3, pp. 831-848, 2012.

[12] H. . A. Latief, "Penelitian Tindakan Kelas Pembelajaran Bahasa Inggris H.M. Adnan Latief," Journal, no. 4, 2018.

[13] A. Popescu, "Communication strategies for developing the learner's autonomy," Procedia - Soc. Behav. Sci., vol. 116, pp. 3489-3493, 2014, doi: 10.1016/j.sbspro.2014.01.789.

[14] Dörnyei, Z., \& Scott, M. L. (1997). Communication Strategies in a Second Language: Definitions and Taxonomies. Language
Learning,
$47(1)$
173-210.

https://doi.org/http://dx.doi.org/10.1111/0023-8333.51997005 